\title{
Süleyman Hakîm Ata'dan Seyyid Nigârî’ye Ahmet Yesevî Geleneğinin Devamı Yahut İki Beytin İzinde ${ }^{1}$
}

\section{Parvana BAYRAM ${ }^{2}$}

Öz

Ahmet Yesevî’nin öğrencisi olan Süleyman Hakîm Ata (doğ.1091/92-öl.1186)'nın Türkistan topraklarının İslamiyet'i tanıyıp kabullenmesinde önemli bir yeri olmuştur. Onun, "Barça Yahşı Men Yaman/Barça Buğday Men Saman" ve "Her Geçeni Hızır Bil/Her Geceni Kadir Bil" dizeleri birer vecize gibi asırlardır dilden dile dolaşarak günümüze kadar ulaşmıştır. Hakîm Ata'nın "Barça Yahşı Men Yaman/Barça Buğday Men Saman" dizesi Türk İslam tasavvufunda en büyük düşman olan nefsin, benliğin yerilmesi için önemli bir vasıta olmuştur. "Her Geçeni Hızır Bil/Her Geceni Kadir Bil" dizesi ise bir Müslümanın nasıl yaşaması gerektiğini göstermesi ve hayata bakış açısını şekillendirmesi açısından önem arz etmektedir. Çalışmada, Ahmet Yesevî’nin öğrencilerinden olan Süleyman Hakîm Ata'ya atfedilen iki beytin 12. yüzyıldan 19. yüzyıla uzanan serüveni, Nakşî-Yesevî çizgisinin edebiyattaki yansımaları ve Seyyid Nigârî divanındaki iki terciibentten hareketle bu şiirlerin günümüz insanına verebileceği mesajlar üzerinde durulacaktır.

\author{
Anahtar Sözcükler \\ Süleyman Hakîm Ata \\ Reşahât \\ Yesevilik \\ Seyyid Nigârî
}

Makale Hakkında

Geliş Tarihi: 13.04.2021

Kabul Tarihi: 13.07.2021

Doi:

10.20304/humanitas.915274

\section{From Suleyman Hakîm Ata to Seyyid Nigari: Reflection of Ahmet Yesevi Tradition in Literature or On Trace of Two Couplets}

\begin{abstract}
Süleyman Hakim Ata (1091/92-1186), a student of Ahmet Yesevi, had an important place in the lands of Turkistan to recognize and accept Islam. The verses written by Hakim Ata including "Barça Yahşı Men Yaman/Barça Buğday Men Saman" and "Her Geçeni Hizır Bil/Her Geceni Kadir Bil" have been reached until now through many centuries. On the other hand, the verse of "Barça Yahşı Men Yaman/Barça Buğday Men Saman" showed Muslims how to live and shape the perspective of them. In this study the issues such as adventure of 2 couplets belonging to Suleyman Hakim who has been student of Ahmet Ata Yesevi from 12th to 19th century, reflection of Nakşi-Yesevi trend to literature and the messages given by these poets to human being living in our modern life will be emphasized.
\end{abstract}

Keywords

Süleyman Hakîm Ata

Reşahat

Yasawism

Nigârî

\section{About Article}

Received: 13.04.2021

Accepted: 13.07.2021

Doi:

10.20304/humanitas.915274

\footnotetext{
1 Bu makale, 28-30 Nisan 2016 tarihinde Ankara'da gerçekleştirilen I. Uluslararası Hoca Ahmet Yesevî Sempozyumunda "Süleyman Hakîm Ata'dan Seyyid Nigârî’ye Ahmet Yesevî Geleneğinin Devamı yahut İki Beytin İzinde: "Her Geçeni Hızır Bil/Her Geceni Kadir Bil” veya "Barça Yahşı Men Yaman/Barça Buğday Men Saman” başlığıyla sunulmuş bildirinin gözden geçirilmiş ve yeniden düzenlenmiş şeklidir.

2 Doç. Dr., Mehmet Akif Ersoy Üniversitesi Fen Edebiyat Fakültesi, Türk Dili ve Edebiyatı Bölümü, Burdur/Türkiye,pbayram@mehmetakif.edu.tr, pervane32@yahoo.com, ORCID: 0000-0003-3051-3395
} 


\section{Giriş}

12-13. yüzyıllar, tasavvuf erbabının, özellikle Türk mutasavvıflarının yetişmesi bakımından oldukça velut bir dönemdir. Bu dönemde yetişen İmam Gazalî (doğ.1059öl.1113), Abdulkadir Geylanî (doğ. 1077- öl.1166), Ahmet Yesevî (doğ. 1093- öl. 1166), Nizâmî Gencevî (doğ. 1141- öl. 1209), Feridüddin Attar (doğ. 1145- öl.1220), Şehâbeddin Sühreverdî (doğ. 1154- öl. 1191) İbnü’l-Arabî (doğ. 1165- öl. 1240), Şems-i Tebrizî (doğ. 1185-öl. 1248), Mevlânâ Celâleddin Rûmî (doğ.1207- öl. 1273), Sadreddin-i Konevî (doğ. 1210- öl. 1274), Davud el-Kayserî (doğ. 1238- öl. 1350) ve Yunus Emre (doğ. 1238- öl. 1320) gibi mutasavvıflardan bazıları Türk kökenli olup İslam dininin Türkler arasında yayılması ve Allah sevgisinin insanların gönlünde yer etmesi yönünde çabalamışlardır. $\mathrm{Bu}$ şahsiyetlerin her birinin tasavvuf tarihinde ayrı bir önemi vardır. Özellikle Türk toplumları arasında geniş halk kitlelerine hitap ederek İslamiyet'in bütün Türk boyları arasında yayılıp sevilmesini sağlayan Hoca Ahmet Yesevî’yi özel olarak anmak gerekir. Menkıbevi hayat hikayesine göre Ahmet Yesevî, Peygamberin kutlu müjdesine mazhar olmuş ve kendi şiirlerinde de vurguladığ 1 gibi doğmadan dört yüz sene önce doğumu müjdelenmiş, kendisine ulaştırılması düşünülen emaneti özenle ayrılıp sahabeden Arslan Baba'ya teslim edilmiştir (Köprülü, 1976, s. 28).

Ahmet Yesevî (doğ. 1093- öl. 1166), Türk tasavvuf edebiyatının önemli isimlerinden olup Yûsuf Hemedânî’nin (doğ. 1048- öl. 1140) öğrencisidir. Hem şair hem de âlim bir şahsiyet olan Yesevî, sade Türkçesi ve halkın anlayıp gönül verdiği şiirleriyle edebiyatın, özellikle de şiirin kitleler üzerindeki etkisini ön plana çıkarmış; aynı zamanda yüzlerce öğrenci yetiştirip irşat için Anadolu'ya göndermiştir.

Türk tasavvuf edebiyatının kurucularından olan Ahmet Yesevî, sade Türkçe ve millî veznimiz hece ile söylediği hikmetleriyle İslam dininin bütün ahkâmını Türk boyları arasında yaygınlaştırıp pekiştirmiştir. Ahmet Yesevî’nin kimi kaynaklarda sayısı 14 bin, kimisinde ise 99 bin olarak gösterilen müritleri, Türkistan'ın çeşitli bölgelerine, Kafkaslara, Anadolu’ya oradan da Balkanlara akın etmiş; Türk hikmetini, İslam ilim ve ahlakını bu topraklarda yeşertip yaymışlardır. Ahmet Yesevî, aşağıdaki hikmetinde bu durumu şöyle ifade etmiştir:

Dört yüz yıldan sonra çıkıp ümmet olacak

Nice yıllar dolaşıp halka yol gösterecek

On dört bin âlimler hizmet eyleyecek

O nedenle altmış üçte girdim yere (Bice, 2015, s. 7). 
Vefatından sonra bile takipçileri üzerinde manevi tasarrufu bulunan Pîr-i Türkistan Ahmet Yesevî, Türkistan dışındaki topraklarda da İslam'ın tanınmasını sağlamıştır.

Ahmet Yesevî gibi Süleyman Hakîm Ata’nın da Türkistan topraklarının İslamiyet'i tanıyıp kabul etmesinde önemli bir yeri vardır. Ahmet Yesevî’nin önemli halifelerinden olan Süleyman Hakîm Ata da hocası gibi şiiri, kitlelere ulaşmada bir araç olarak kullanmış ve hikmetleriyle insanları irşat etmiştir. Süleyman Hakîm Ata, Ahmet Yesevî’nin üçüncü halifesi olup daha çok Kuzey Türkleri arasında meşhurdur. Aynen mürşidi gibi o da düşünce ve görüşlerini şiirleri vasıtasıyla halka ulaştırmıştır. Kaynaklarda Bakırgan Kitabı, Ahir Zaman Kitabı ve Hazret-i Meryem Kitabı olmak üzere üç eserinin varlığı bilinmektedir (Güzel, 2008, s. $96,105,110)$.

Süleyman Hakîm Ata şiirlerinde, girift konuları arı duru Türkçesiyle, herkesin kolaylıkla anlayabileceği bir şekilde söyleyip kitleleri arkasından sürüklemeyi başarmıştır. Bu şiirler içinde iki önemli dize vardır ki klasik metinlerimizin önemli kaynakları arasından süzülüp günümüze kadar ulaşmıştır. Bu dizeler, İranlı mutasavvıf Sâfî Mevlâna Ali bin Hüseyin'in Reşahât-ı Aynü'l-Hayat adlı eserinde geçmektedir (Kısakürek, 2015, s. 4,75).

Yesevilik ve Süleyman Hakîm Ata ile ilgili bilgiler son yüzyılda daha çok Fuat Köprülü tarafından araştırılıp bilim alemine duyurulmuştur. Köprülü, Reşahât Tercümesi’ne istinaden bu hususta şöyle yazmıştır:

Dervişler ahvâlinden Türkî dilde kelimât-1 hikmet-âmiz ve letâif-i ibret-engîzleri Türkistan vilâyetinde ma'rûf ve meşhurdur ve ânların fevâid-i enfâs-i kudsiyyelerindendir. Bu mesel ki halka hüsn-i zan ile hürmet ve her vakti ganîmet bilmek bâbında buyurmuşlardır ki: Her kimi görsen Hızır bil ve her geceyi Kadir bil ve bu mesel ânlara mensuptur ki "kesr-i nefs"te buyurmuşlardır: Barça yahşı biz yaman/ Barça buğday biz saman, yâni cümle yahşı biz yaman/Cümle buğday biz saman. (1976, s. 172; Ali bin Hüseyin, 1853, s. 15-16)

Süleyman Hakîm Ata'dan günümüze ulaşan ve her çağda, çeşitli ortamlarda insanlığa hitap edebilen evrensel değerlerle yüklü bu iki tasavvufi içerikli dizeyi, 12. yüzyıldan 19 . yüzyıla aynı tasavvufî halkanın önemli temsilcilerinden Nakşibendîye tarikatının Halidiye koluna mensup olan ve Amasya'da tekkesi bulunan Seyyid Nigârî, Türkçe Dîvânında iki terciibent içinde yeniden yorumlamıştır.

Yusuf Hemedânî vasıtasıyla birleşen Yesevilik ile Nakşibendiye arasında birçok ortaklık bulunmaktadır. Nakşibendiye'nin Halidiye koluna mensup 19. yüzyıl şairi Seyyid Nigârî (doğ. 1805- öl.1886) de Türkçe Dîvânında Süleyman Hakîm Ata'nın bu iki dizesini iki terciibendinde tercihane olarak kullanmış ve yaşadığı 19. yüzyıl toplumunda yeniden bu 
geleneğin canlandırılıp günümüze kadar ulaşmasını sağlamıştır. İkisi de Müfte'ilün Fâ‘ilün vezniyle yazılan bu terciibentler 7 bentten oluşmaktadır. Her bent kendi içinde 5 beyitten oluşuyor. Edebî özelliği ön planda olmakla birlikte bu şiirler, bir mürşidin müritlerine verdiği öğütlerin niteliği açısından da çok önemlidir.

Seyyid Nigârî̀nin şiirlerinde ve tasavvuf eğitiminde Ahmet Yesevî tesiri sadece onun öğrencilerinden Süleyman Hakîm Ata'nın bahsi geçen dizeleri ile sınırlı değildir. Seyyid Nigârî, Yesevîye ile Nakşibendiye'nin ortak temellerinden şiirlerinde sıklıkla bahsetmiş, sadece isim olarak değil, coğrafya olarak da Türkistan'ın önemini sürekli vurgulamıştır. Özellikle Nakşî ve Yesevî-Nakşî büyüklerine şiirlerinde göndermelerde bulunmuştur.

Seyyid Nigârî’nin Ahmet Yesevî’nin kendisi ile de birebir edebî-tasavvufî etkileşimi vardır. Özellikle bu etkileşim şairin tasavvufî Çaynâme mesnevisinde bariz bir biçimde görülmektedir. Dost ve irfan meclislerinde içilen çaydan ve onun önemli bir unsuru olan semaverden bahseden, Türk kültür tarihinde çayın kullanımı ve makbul bir içecek olmasıyla ilgili ilk bilgilerin Hoca Ahmet Yesevî’ye dayandırıldığını bilen şair, bu eserde Türkistan mutasavvıflarının pek çoğunun adını anmıştır.

Ahmet Yesevî ile ilgili menkıbelerde onun çayı çok sevdiği ve çayla ilgili söylediği "Bu şifalı bir şeymiş, hastalarınıza bundan içirin ki şifa bulsunlar. Allah kıyamete kadar buna revaç versin.” (Köprülü, 1976, s. 45; Demirci, 1996, s. 21) ifadesinden hareketle Seyyid Nigârî, ilk defa Türk edebiyatında tasavvufi içerikli Çaynâme mesnevisini yazmıştır. Aynı etkileşim daha sonra 20. yüzyılın mutasavvıf şairi Alvarlı Muhammed Lutfî Efe'de de görülmektedir. O da Ahmet Yesevî ve Seyyid Nigârî'den etkilenerek "çayın camları" redifli, hece vezniyle 17 bentlik bir şiir yazmıştır (Kutlu, 2013, s. 519-520).

19.yüzyılda yetişen ve mücadeleci şeyh kimliğiyle Azerbaycan ve Anadolu tasavvuf edebiyatı tarihinde önemli rol oynayan Seyyid Nigârî, Azerbaycan'ın Karabağ bölgesinde doğup büyümüş ve Çar Rusyası'nın baskılarından dolayı Anadolu'ya göçmek zorunda kalmıştır. Seyyid Nigârî, kendisinden önceki İslam mutasavvıflarının ve âlimlerinin eserlerine vakıf olmuş bir âlim, sufi, şeyh; aynı zamanda hece ve aruz ölçüsüyle çok güzel şiirler yazan Fuzûlî takipçisi mutasavvıf bir şairdir. Şairin Türkçe Dîvânındaki şiirlerin neredeyse tamamı; Çaynâme ve Nigarnâme isimli iki mesnevisi tasavvufi konuda yazılmış olup bu eserlerde tasavvufi mecaz ve ıstılahlar başarılı bir şekilde kullanılmıştır (Bayram, 2008b, s. 133).

Seyyid Nigârî, Türkçe Dîvânında da kendisinden önceki birçok tarikatın ismini zikretmiş, zaman zaman Yeseviye'nin, genellikle ise Nakşibendiye tarikatının ileri gelenlerini çeşitli vesilelerle anmıştır. Bu tarikat ve mezheplerden daha çok Nakşibendiye, Mevleviye, 
Melamiye, Aleviye; Haricilik, Rafizilik, Süfyanilik, Yezidilik, Mervanilik, Heccacilik ve Şirmanilik gibi terim ve kavramlar onun şiirlerinde çok geçmektedir. Nakşibendiye tarikatına mensup olan şair, Mevleviliğe ve Melamiliğe de 1lımlıdır. "Hâk-i pâyin tâc-1 serimdir diyü/Gerden eğer 'arş-1 mu'allâ bana” (Bilgin, 2017, s. 26) diyen ve Türkçe Dîvânında çok sayıda naata yer veren Seyyid Nigârî, Âl-i Abâyı sevmekte olup Haricilik, Rafızilik, Süfyanilik, Yezidilik, Mervanilik, Heccacilik ve Şirmanilik gibi kavramları ve mensuplarını şiirlerinde sürekli yermiştir (Bilgin, 2017, s. 430).

Şiirlerinde vahdet-i vücut felsefesine geniş yer veren şair, Allah ve peygamber sevgisini, Allah'ın birliği ile ilgili hususları samimi ve başarılı bir şekilde ifade etmiştir. Hüsn ve aşk, Bezm-i Elest gibi mazmunlara; tecrit, ilahi şarap, aşk, aşk şarabı, tecelli, cezbe, fenafillâh, rabıta, ayrılık ve harf sembolizmi gibi konulara önem vermekle birlikte, sufilerin gizli halleriyle ilgili bilgiler; zahitlere ve yalancı sofulara, seyr ü süluk ve tarikatlara bakış gibi hususlar da Seyyid Nigârî’nin şiirlerinin temel konularındandır. Ayrıca şeyh kimliği dolayısıyla Seyyid Nigârî, birçok şiirinde hikmet geleneğini devam ettirmiştir.

Seyyid Nigârî'nin mesnevilerinde klasik mesnevi şairlerinin, özellikle 18. yüzyıl şairi Şeyh Galib'in Hüsn ü Aşk adlı mesnevisinin etkisi büyüktür. Bu mesnevideki sembolik mazmun ve alegorik unsurların birçoğu farklı biçimde Çaynâme mesnevisinde de geçmektedir. Şair bu eserde semavere ve çaya çeşitli tasavvufi anlamlar yüklemiştir. Çaynâme-i Seyyid Nigârî adlı aruzun Mef û lü/Me fâ i lün/Fe û lün vezniyle yazılan eser, 521 beyitlik tasavvufi bir mesnevi olup tasavvuftaki on sekiz bin âlem kavramını da çağrıştıracak şekilde 18 bölümde tamamlanmıştır.

Oldukça orijinal bir konu ve olay örgüsü çevresinde şair; "Bağrı yanık” âşıklara teşbih ettiği semaverden, Ahmet Yesevî’nin çay ile ilgili menkıbesi etrafında şekillenip dertli âşıklara şifa veren çayın dost meclislerinde içilmesinden bahsetmiştir. Seyyid Nigârî eserde, Turan'dan İran'a, Türkistan'dan Şirvan ve Karabağ’a kadar bütün Türk yurtlarına, özellikle Ahmet Yesevî diyarına ve Yesevî’nin kendisi de başta olmak üzere bütün tasavvuf erbabına göndermelerde bulunmuştur. Çaynâme’nin beşinci bölümünde, 'Bu evsaf-l semâver-i dilgüşâdan bir vasf-ı dil-ârâ-yı ferah-fezâdır" başlığı altında semaverin özelliklerini anlatan şair, semaveri ney ile mukayese ederek Mevlevilik tarikatına da göndermede bulunmuştur:

Semaver ne çınar ne de gülnardır, onun âşıklığına delil içindeki nardır, semaver ne bezeklidir ne de renkli; altın renginde olması onun kendi özelliğidir. Altın suyuna boyanan onun zahiridir, içi aşk ateşiyle yanmıştır. Semaverin canı gönül ehlinin canıdır, onu da semaver gibi aşk ateşiyle yakmışlardır. Semaver bir muammalı dairedir ki içinde od ile su bir arada bulunmaktadır. 
Semaverin ateşinin yandığı kısım öd ağacı micmeridir, içindeki od ise gülnardır (Bilgin, 2017, s. 601-602).

Burada İbrahim Peygamberin ateşe atılması olayına telmihte bulunan şair, semaverin suyunun dirilik suyu olduğunu ifade eder.

Semaver kaynamaz, âdeta coşar ve bu coşma, bir can cümbüşüdür. Kaynayan suyun yakıcı buharı uçan kuşa benzer, fokurtuyla kaynayıp dökülen sular ise Süleyman Peygamber'in Hüdhüd'üne benzemektedir. Semaver Simurg kuşuna, iki tarafındaki kulpu ise bu kuşun kanatlarına benzer. Bu haliyle semaver sanki Dahhak'tır ve iki omzunda insan beyni yiyen yılanlar bulunmaktadır. Dûd-keşi Mevlevi külahı olup içi ve dışı dertle yanmıştır. Semaverin dem-keşi Mesih'in nefesi, aldığı her nefes ise Meryem'in kokusudur. Semaverin başındaki çini (porselen) çaydanlık ise sanki tahtında oturan Çin padişahıdır. Semavere ve çaydanlığa yandan bakıldığında sanki başında tacıyla oturmuş bir şahla karşılaşıyorsun (Bilgin, 2017, s. 602).

Tasavvufun gâyesi insan-1 kâmile ulaşmaktır. Bunun için de insanın Hakk'1 ve kendisini idrak etmesi gerekir. İnsan-1 kâmile ulaşmanın esas yolu aşktan geçer. Bu sebeple bu yola baş koyanların aşk ateşiyle pişerek olgunlaşması gerekir. Mevlana’nın "Hamdım, piştim, yandım.” ifadesi de aslında âşıklığın bir özetidir.

Eserin altıncı bölümünde, "İstimdâd kerden-i nâzım bad-ez-lutf-ı Perverdigâr ez-tab '- $\iota$ şeker-güftâr u ez-aşk- s şîtîn-kâr” başlığı altında şair, aşk üstadına hitap ederek çayı, kokusu itibariyle Hıta miskine benzetir. Seyyid Nigârî, burada Ahmet Yesevî’nin çayla ilgili yukarıda bahsi geçen menakıbına da göndermede bulunmuştur.

Ey tâb'-1 şirin ey aşk-1 üstâd

Tarh eyleyelim bir özge bünyâd

Ol nâfe-i âhû çây-1 hoş-bû

İhvân-1 tarîk zikri ya Hu (Bilgin, 2017, s. 602).

Şair, burada çay hakkında daha birçok benzetme kullanmıştır:

Çayın başka özellikleri de vardır ki çok şifalıdır, özellikle veba hastalığının ilacıdır. Çay, bin derdin dermanıdır ama tiryak değildir, uyuşturucu özelliği olmayıp vücudu zehirli maddelerden temizlemektedir. Bu sözlerimi boşuna değil, demli bir çay için söylüyorum. Zira çay, Çin ve Hita ceylanı, Hita miski ve Maçin gülüdür. Şüphesiz ki inayet mazharıdır, ondaki kemalin vasfı sonsuzdur. Çay, gönül alan bir peri tarafindan yetiştirilmiş olup nefesi misk, vücudu gül kokuludur. Çay, nefes erbabı, gönül ehlidir, bedeni yanık, yanakları gül, vücudu dağlıdır. Bu onun âşıklığının delilidir. Çay limon ile içilirse başka bir lezzeti ortaya çıkar. Çayın tabı şirin, mizacı hoştur. Bazen onu süt ile de karıştırıp içiyorlar. Eğer çay meclisinde kaymak da olursa bu neşeden, bu keyiften usanılmaz (Bilgin, 2017, s. 603). 
Sonra şair, söze hitap ederek

Ey söz Hüması, şimdi kanatlan, Fransa ve İngiltere'ye git ve şeker dağlarını denkleştir, gemiyle buraya getir. Oralarda çok durma, ilahî bir yardım ile Mısır’a geç, oradan şeker al, limon almayı da unutma. Sonra İsfahan yollarına düş, mesafeler aşarak hızlıca Turan'a geç. Sefer sırasında yemeden, içmeden ve uyumadan Horasan'a geç, orada işlerin daha kolay çözülür. Geçtiğin yerlerde Bistam Şahı (Bazeyid-i Bistamî), Cem Şah ve Tus şehrinin ileri gelenleri vardır, onlar lâhut âleminin şahlarıdır. Onların ayakları altında nâsut kuşu-insanlık kuşu vardır. Yol serdarının adı Tayfur'dur, onun mezarı ziyaretçilerini sevindirir. Sen feyz kanadını o mekândan al, tayy-i mekân ederek zamandan geç. Mukaddes Meşhed şehrine var. Allah'ı anarak oradan da kanatlan ve Tus şahını gör. O, kürsüsünde oturmaktadır. Sekizinci cennetin, imamet dayanacağının şahı odur. Onun huzurundaki hizmetini sadakatle tamamla ve kanatlanarak Cam şehrine git. Abdurrahman Cami’ye gönül ver. O, dört yüzün esasıdır ve keramet miracının temelidir. Oradan Harezm'e geç, orada Pehlivan'ın (Pehlevan Muhammed) mezarının toprağını öp, o kimyadan feyz al, reh-nümalar diyarına azm ile evliyalar mekânını seyr et. O, nefesi Mesih-i sara, her bir nazarında bin iksir, bin cihangir olan, irfan kasrının (Kasr-1 Arifan) tahtında oturan o serdarın, evliyalar padişahı ve Buhara serveri Bahaeddin Nakşibend'in mezarını, dergâhını ziyaret et, ellerini kaldırarak senin şiir âleminde kanatlanman için Allah'a dua et. O topraklardan güç alarak Timur gibi cihangirler padişahı ol. Daha sonra o yerleri de öperek kanatlan ve oradan Semerkant şahının- yol üzerinde olan Ubeydullah Ahrar'ın, ata bindiği demde kılıcı Rum'da oynayan o fena ve beka mülkünün sultanının da mezarını öp ki senin şiir vadisinde kanatlanmana yardım etsin. Bundan sonra kanatlan ve Hıta yollarına doğru uç, o misk ve amberler diyarına vardığında ahular seni karş1layacak, yüzünü görmek için canlarını, sözlerini duymak için varlarını vereceklerdir. Çünkü onlar sende var olan ilahi aşk1 ve senin bu aşk uğruna masivadan geçtiğini bilirler. Eğer sen bir nefesinde Ya Hu dersen, meclisine bütün aslanlar ve ceylanlar toplanacaktır der. (Bilgin, 2017, s. 605-619)

Gönlünü kendinden tecrit ederek, ziyaret için geniş bir coğrafi alan çizen şair, Horasan erenlerini, Meşhed'de şehit edilen imamların makamını, oradan Afganistan, Buhara ve Semerkant'taki evliya mezarlarını ziyaret ettikten sonra son durak olarak Türkistan'a yönelir. Şairin, burada Hita mülkü dediği yer, Türkistan ve Ahmet Yesevî Türbesi'nin olduğu yerlerdir. "Meclisinde aslanlar ve ceylanlar toplanacaktır" ifadesiyle de Hacı Bektaş Velî’yi kastetmektedir. Seyyid Nigârî burada Hüseyin Vâiz Kâşifî’nin oğlu Fahreddin Sâfî (öl. 939/1532-33)'nin Reşahât-l Aynü'l-Hayat'ına ve Câmî'nin Nefehatü'l-Üns'üne de göndermelerde bulunarak meşhur evliyaların ruhaniyetinden feyz almayı diler. 
Her bir nefesi Mesîh-âsâ

Her bir nazarı nazîr-i kimyâ

Enfâs-1 nefîsi rûh-1 Nefahât

Eltâf-1 kelâmı reşk-i Reşahât (Bilgin, 2017, s. 620).

Seyyid Nigârî, Süleyman Hakîm Ata'ya isnat edilen "Her geçeni Hızr bil/Her geceni Kadir bil" ve "Barça Yahşı Men Yaman/Barça Buğday Men Saman” şeklindeki iki dizeyi tercihane şeklinde kullanarak iki ayrı terciibent yazmıştır. Bu dizeler, Seyyid Nigârî Dîvânı'ndaki 832 ve 833 numaralı terciibentlerde kullanılmıştır.

\section{“Her Geçeni Hızr Bil/Her Geceni Kadir Bil” Dizesiyle Yazllan Terciibendin İncelenmesi}

Seyyid Nigârî'nin, Süleyman Hakîm Ata'dan alarak terciibent içinde değerlendirdiği "Her geçeni Hızır bil/Her geceni Kadir bil” dizesi, Hakîm Ata döneminde ve o zamandan günümüze kadarki dönemde hem halk arasında hem de tasavvuf erbabı arasında sıklikla kullanılmıştır.

1.Bent

Fakrı dilâ fahr bil

Fahrı derin fakr bil

“İne ma'a'l-“usr” bil

Çekme elem yüsr bil

Kendini bâ-kesr bil

Nefsini bî-kadr bil

Tâatını vizr bil

Bu sözi bî-özr bil

Her geçeni Hızr bil

Her geceni Kadr bil (Bilgin, 2017, s. 540).

Birinci bentte, "Ey gönül, fakirliğini fahrın bil (fakirliğinle övün), asla sıkıntı çekme ve "Her güçlükle beraber bir kolaylığın olduğunu" bil. Kendini kusurlu, nefsini ise kıymetsiz bil. (Hor gör). İbadetini, taşıman gereken bir yük, bu sözlerimi ise kayıtsız şartsız kabul edilip uyulması gereken bir nasihat olarak algıla: Her geçeni Hızır, her geceni Kadir bil” denmektedir.

İlk iki dizede şair, Hz. Muhammed'in "Fakirliğim övüncümdür" anlamına gelen hadisine telmihte bulunmuş, ikinci beyitte ise İnşirah suresinin 5. ayetini (Muhakkak güçlükle beraber bir kolaylık vardır. 94/5) iktibas etmiştir. Burada, tasavvuftaki zamana uyum sağlayıp zamanı iyi kullanmak anlamındaki "ibn-i vakt olma” düşüncesi de vurgulanmaktadır. İçinde bulunulan her anı dolu dolu yaşamak ve değerlendirmek, karşılaşılan her olay ve şahıs 
nezdinde ilahi bir hikmet olabileceği düşüncesiyle yaşamak ve olaylara ibret gözüyle bakmak gerektiği üzerinde durulmuştur.

II. Bent.

Söyleyelim ey püser

Dinle bu pend-i peder

Anla nedir kim haber

Böyle diyüp râh-ber

Var bu yolda hatar

Kibrden eyle hazer

Kendini gör bî-basar

Eyleme 'ayba nazar

Her geçeni Hızr bil

Her geceni Kadr bil (Bilgin, 2017, s. 540).

İkinci bendin nesri şöyledir: "Ey oğul, biz söyleyelim, sen de bu baba nasihatini dinle. Peygamberin kibir konusunda söylediklerini düşün ve kibirli insanların tuttuğu yolun çok tehlikeli olduğunu görüp kibirden kork. Kendini kör olarak bil ve asla ayıpları ve kusurları görme. Her geçeni Hızır, her geceyi ise Kadir bil."

Bu bentte şair, kibrin zararları ve insanı felakete sürükleyeceği konusunda uyarılarda bulunmuştur. Zira, insanlığa rehber olan peygamberimiz bu dünya yolculuğunun tehlikeli olduğunu ve özellikle kibirden ve kibirlilikten korkup çekinmemizi emretmiştir. İnsanoğlunun huzurlu bir yaşam sürmesi için gözlerini kötü şeylere kapatarak asla ayıba ve kusura bakmaması, böylesi durumlarda kör gibi davranması gerektiği üzerinde durulmuştur.

III. Bent.

Her ne direm k1l 'amel

Eylemegil der-bagal

Eyleme tûl-i emel

Kendüni gör der-halel

Gayra nazar it güzel

Pend budur bî-bedel

İmdi degül tâ ezel

Böyledir ey dil mesel

Her geçeni Hizr bil

Her geceni Kadr bil (Bilgin, 2017, s. 541).

Üçüncü bentte ise "Sana her ne söylersem sözümü dinle ve ona uy. Kimsenin yanında sığıntı olarak yaşama, kimseye minnet eyleme. Tûl-i amel olan boş işlerle uğraşma, kendini 
her zaman kusurlu bil. Kendinden başkasına hep hoş nazarla bak. En değerli, eşsiz nasihat budur ve ey gönül, bu nasihat sadece şimdi değil ta ezelden beri bir atasözü değerindedir. Her geçeni Hızır, her geceyi ise Kadir bil.” denmektedir.

Kendini her zaman kusurlu bilmek ifadesi, bütün olumsuzlukları kendinden bilme düşüncesi Ahmet Yesevî’den Süleyman Hakîm Ata’ya, ondan Hacı Bektaş Velî’ye (“Her ne arar isen kendinde ara" dizeleriyle), ondan da birçok tasavvuf erbabına ulaşarak günümüze kadar devam etmiştir.

IV. Bent.

Ey dil-i şî̂n-zebân

Söyleme hergiz yaman

Bed diyene söyle cân

Kimseye virme ziyân

Eyleyelim hoş beyân

Tâ‘atın eyle nihân

Olma ebed bed-gümân

Pendim işit el-emân

Her geçeni Hızr bil

Her geceni Kadr bil (Bilgin, 2017, s. 541).

Dördüncü bentte, "Ey tatlı dilli gönül, asla kötü söz söyleme, kimseye zarar verme ve sana kötü söz söyleyene sen tatl1lıkla "can” diye karşıl1k ver. Her zaman hoş sözler söyle ve ibadetini gizli yap, aman dikkat et, asla kötü zanda bulunma ve bu nasihatimi dinle: Her geçeni Hızır, her geceyi ise Kadir bil” denmiştir.

$\mathrm{Bu}$ bentte üzerinde durulan husus, insanoğlunun tatlı dilli olması, kendisine kötü muamelede bulunana bile iyilikle karşıllk vermesi; güzel sözler söyleme ve güzel işler görme alışkanlığı edinmesi ve en esası da ibadetlerini halka göstermek için değil, sadece Hak için yapması gerektiğidir.

V. Bent.

Ey dil-i şîîn-makâl

Eylemegil kîl ü kâl

'Aşk ile ol zevk al

Gör ki nedir keyf ü hâl

Varına virgil zevâl

Yüz vire tâ kim visâl

Söyleyelim bir misâl

Eyle 'amel bul kemâl 
Her geçeni Hızr bil

Her geceni Kadr bil (Bilgin, 2017, s. 541).

Ey tatlı sözlü gönül, dedikodu yapma. Her zaman aşk içinde bulun ve bu hayattan zevk al. O zaman dünyanın ne kadar güzel ve yaşamaya değer olduğunu göreceksin. Varını yok et. İşte o zaman sevgiliye kavuşabileceksin. Bir misal verelim de buna amel eyle ve kemal bul: Her geçeni Hızır, her geceyi ise Kadir bil.

Burada, tatlı sözlü olmanın, dedikodu yapmamanın gerekliliği ve insanoğlunun her anını aşk ile yaşayıp bütün varlıklara aşk nazarıyla bakması; gerçek aşkı bulmak ve vahdete ermek için varlıktan geçmek gerektiği vurgulanmaktadır.

VI. Bent.

Ey dil-i şîîn-dehân

Zevk gerek ân ân

Keşf ola sırr u nihân

Tâ bilesin bî-nişân

Sendedir ol bî-gümân

Ammâ diyem bir beyân

Eyle 'amel el-emân

Çünki dimiş 'ârifân

Her geçeni Hızr bil

Her geceni Kadr bil (Bilgin, 2017, s. 542).

Ey tatlı ağızlı gönül, güzelliğin, melahatin de zevki gerek. Gizli sırlar aşikâr ola ve sen de nişansız, açıklamasız olarak bunlara vakıf olasın. Şüphesiz ki bu zevk de sende vardır, ama ben yine de bir daha açıklayayım: Aman dikkat et de bu denilenlere uy, zira arifler "Her geçeni Hızır, her geceyi ise Kadir bil.” demişlerdir.

Burada vurgulanan husus, insanoğlunun ahsen-i takvim üzere yaratılması; en mükemmel varlık olan insanın bütün güzellikleri kendinde bulundurup bunu hissetmesi, kendi nefsi ve ruhu üzerinde bir kuyumcu titizliği ile işleyerek bütün gizli sırlara vakıf olma çabası içinde bulunması gerektiğidir.

VII. Bent.

Mîr Nigârî cilâ

Vir dile sâf eyle tâ

Keşf ola bahr-1 fenâ

Yüz vire dürr-i bekâ

Mahv ola gayr-1 Hudâ 


\section{Nefy ola illâ vü lâ}

Bil bu sözi kîmyâ

Tasdîk eyle innemâ

Her geçeni Hizr bil

Her geceni Kadr bil (Bilgin, 2017, s. 542).

Ey Mir Nigârî, gönlüne parlaklık ver ve gönlünü o kadar saflaştır ki fena denizi senden kopup ayrıla, ebediyet incisi sana nasip ola. Gönlünde Allah'tan gayrı ne varsa hepsi mahvolup gönlünden sürgün edile. Sen bu sözü ilaç olarak kabul et ve sürekli buna uy: Her geçeni Hızır, her geceyi ise Kadir bil.

Burada, gönül temizliğinin ve tasfiyesinin önemi ve sürekli Hakk’1 düşünüp zikretmekle, Hakk'ın rızasına uygun yaşamakla vahdete erişilebileceği üzerinde durulmuştur.

İlk terciibentte yedi bent içinde sırasıyla öne çıkarılan hususlar şöyledir: İnsanoğlu, her türlü ortamda kalbini ferah tutmalı, asla üzüntüye yenik düşmemelidir. Her zaman nefsini yenerek kusurun kendinde olduğunu düşünmeli, peygamberin yolundan giderek kibir ve riyadan çekinip ayıp ve kusurlar karşısında kör olmalıdır. Kimseye minnet etmeden yaşamalı, ömrünü boş işlerle tüketmemelidir. Kendisinden başka herkese ve her şeye hoş nazarla bakmalıdır. Kimseye eliyle veya diliyle zarar vermemeli, asla kötü zanda bulunmamalıdır. İbadetlerini de gösteriş için değil, yalnız Allah için ve gizlice yapmalıdır. Dedikodudan uzak olmalı, her zaman aşk içinde ve hayattan zevk alarak yaşamalıdır. Şayet böyle yaparsa gerçek sevgiliye kavuşabilir.

\section{“Barça Yahşı Men Yaman/Barça Buğday Men Saman” Dizesiyle Yazılan Terciibendin İncelenmesi}

Üzerinde duracağımız "Barça Yahşı Men Yaman/Barça Buğday Men Saman" şeklindeki 2. dize, Seyyid Nigârî Dîvânındaki 833 numaralı terciibende tercihane olarak alınmıştır. Herkes anlamına gelen "barça” kelimesi Dîvânda "parça" şeklinde yazılmıştır.

I. Bent.

Söyleyim ey tâlibân

Vir bu söze gûş-1 cân

Şevk ile ehl-i dilân

Söyleye ey bî-nişân

Dâda yetiş el-emân

Vir bana senden nişân

Mahv ola benlik hemân

Tâ diyelim her zamân 
Parça yahşı biz yaman

Parça buğday biz saman (Bilgin, 2017, s. 543).

Ey talipler, ey müritler, söylüyorum, bu sözlerimi can kulağıyla dinleyin: Sevgilide fena bulup kendi benliğinden soyutlanmış talip ve gönül ehli olanlar şevk ile “Aman Allah'ım ne olur yardım et ve kendinden bana bir nişan, bir iz ver ki sana ulaşmamız kolay ola ve bu benlik kolaylıkla benden gide" diye söylesinler. Biz de her zaman "Herkes iyi, biz kötüyüz; herkes buğday gibi değerli, biz ise saman gibi havai ve gereksiziz.” diyerek zikredelim.

Aynı zamanda bir Nakşibendi şeyhi olan Seyyid Nigârî, burada müritlerine hitap ederek fenafillaha ermek için sürekli dua ve tövbe etmeleri ve bütün kusurları kendilerinde görüp herkese hüsn-i zanla bakmaları gerektiğini vurgulamıştır.

II. Bent

Mistabada bir makâm

Ahz eyleye müstedâm

Elde duta mey-i câm

Devr eyleye subh u şâm

Bilmeye hâl ü makâm

Nefy ola nâmûs u nâm

Tâ kıra nefsin tamâm

Söyleye bunı müdâm

Parça yahşı biz yaman

Parça buğday biz saman (Bilgin, 2017, s. 543).

İlahi aşka talip olanlar meyhanede daima hazır bulunacakları bir makam edinmeliler. Burada daima ellerinde şarap kadehi tutarak sabah akşam sarhoşça devretmeli, dönüp durmalılar. Namusu, adı hiçe sayarak zamanı ve mekânı unutup kendilerinden geçmeliler. Ta ki nefislerini tamamen yok etmeli ve "Herkes iyi, biz kötüyüz; herkes buğday gibi değerli ve gerekli, biz ise saman gibi havai ve gereksiziz" deyinceye kadar buna devam etmeliler.

Bu bentte, ilahî aşka düşenlerin daima bir pervane gibi mürşid-i kâmilin çevresinde dönüp mâsivâyı terk etmeleri, sürekli Hakk'ı zikrederek kendi nefislerini yermeleri gerektiği vurgulanmıştır. 
III. Bent

Mistabanı bâb bâb

Devr ile k1lgil şitâb

'Aşk ile çek mey-i nâb

Tâ olasin müstetâb

Sende doğa âf-tâb

Açıla cümle hicâb

Dil göre kendin harâb

Eyleye bunı hitâb

Parça yahşı biz yaman

Parça buğday biz saman (Bilgin, 2017, s. 543).

Ey âşık, meyhaneyi o baştan bu başa koştururcasına devreyle. Halis şarabı aşk ile başına öyle bir çek ki bu hâlinle herkes tarafindan beğenilesin. Ta ki sende güneş doğa, için aydınlana ve bütün perdeler gönlünden kaldırıla. Bu halinle gönlün, kendinin harap olduğunu görüp, durmadan "Herkes iyi, biz kötüyüz; herkes buğday gibi değerli ve gerekli, biz ise saman gibi havai ve gereksiziz." zikrine devam etsin.

Burada, ilahi aşkla coşan müridin bütün perdeleri, makamları aşıp sevgilisine kavuşması ve bu haldeyken bile nefsini yermesi gerektiği üzerinde durulmuştur.

IV. Bent

Şâm u seher külli hâl

Elde geze câm-1 al

Söyleye şîîn-makâl

Bezme sala kîl ü kâl

'Aşka gire lâ übâl

Gözleye bir meh-cemâl

Virmeye mihre zevâl

Söyleye erbâb-1 hâl

Parça yahşı biz yaman

Parça buğday biz saman (Bilgin, 2017, s. 544).

Âşık, gerek sabah akşam, bütün vakitlerinde elinde al-kırmızı şarap kadehiyle dolaşarak ve tatlı sözler söyleyerek meclise kargaşa salmalıdır. Tasasız ve endişesiz olarak aşka düşüp bir ay yüzlüyü beklemelidir. Hâl ehli olan âşık, sevgisini yok edip tüketmeden sürekli "Herkes iyi, biz kötüyüz; herkes buğday gibi değerli ve gerekli, biz ise saman gibi havai ve gereksiziz" demelidir. 
Şair, âşıkların naz makamında olduğunu ve bu makamdayken çeşitli şathiyeler söyleyebileceğini vurgulamıştır.

V. Bent

Dem-be-dem ehl-i niyâz

Söyleye ey şâh-1 nâz

'Ömr kûteh himmet az

Derdime ol çâre-sâz

Vir bana sûz u güdâz

Mahv ola mihr-i mecâz

Keşf ola perde-i râz

Söyleyelim 'aşk-bâz

Parça yahşı biz yaman

Parça buğday biz saman (Bilgin, 2017, s. 544).

Niyaz ehli olanlar sürekli, "Ey naz şahı, ömür kısa, yardım az, derdime bir çare kıl, bana aşkının ateşini ve senin yolunda yok olmayı nasip et" demelidirler. O zaman mecazi sevgi yok olur ve sır perdesi aralanır. Biz de aşk içinde, coşkuyla "Herkes iyi, biz kötüyüz; herkes buğday gibi değerli ve gerekli, biz ise saman gibi havai ve gereksiziz." söyleriz.

Şair, vecde gelen âşıkların sevgiliye ulaşmak için devran ederek çeşitli makamları atlayıp sürekli niyaz etmeleri ve bunu yaparken bile nefislerini yermeleri gerektiğini vurgulamaktadir.

VI. Bent

Servin ide ser-nigûn

Gözleye kaşı dü nûn

Okıya ders-i cünun

Ahz ide bî-had fünûn

Eyleye bağrını hûn

Derd ile ola zebûn

Tâ ola derdine çün

Söyleye bunı füzûn

Parça yahşı biz yaman

Parça buğday biz saman (Bilgin, 2017, s. 544).

Gerçek âşık, boynunu servi gibi aşağı eğerek kaşları iki nun gibi olacak şekilde beklemeli, sonsuz ilimleri benimseyerek delilik ilmini okumaya başlamalı, bağrını kan ederek dert ile zebun olmalıdır. Ta ki bu hâl ile derdine bir çare ola ve sürekli bunu söyleye: "Herkes 
iyi, biz kötüyüz; herkes buğday gibi değerli ve gerekli, biz ise saman gibi havai ve gereksiziz."

Bu bentte, gerçek âşıların ilim-irfan sahibi olmaları ve aşk derdiyle dertlenip delilik ilmini, yani aşk ilmini de kesp etmeleri; bu arada kendilerini her zaman hor görüp asla nefislerini şımartmamaları gerektiği vurgulanmaktadır.

VII. Bent

Mîr Nigârî hezâr

Eyleye feryâd u zâr

Açıla zülf-i nigâr

Keşf ola ruhsâr-1 yâr

El vire tâ asl-1 kâr

Ol göre kendin gubâr

Devr eyleye zerre-vâr

Eyleye bunı medâr

Parça yahşı biz yaman

Parça buğday biz saman (Bilgin, 2017, s. 545).

Mir Nigârî, binlerce feryat ve figan eyler iken sevgilinin saçları açıla ve yüzü ortaya çıkıp görüne. İşin aslı ortaya çıka ve o da kendisinin bir toz, bir zerre olduğunu anlaya. Zerre gibi devretmeye başlaya ve bunu da Hakk'a ulaşmada bir sebep olarak göre. O zaman Hakk'a ulaşma yolunda bir zerre gibi dönüp durmalı ve sürekli "Herkes iyi, biz kötüyüz; herkes buğday gibi değerli ve gerekli, biz ise saman gibi havai ve gereksiziz" diye zikretmelidir.

Seyyid Nigârî’nin aşk derdiyle feryat edip ağlaması sonucunda sevgilinin saçları açılıp yüzü görününce, şair kesretten vahdete ulaşacak ve bütün sırlara vâkıf olacaktır. Sevgilinin güzelliği ve ihtişamı karşısında kendisinin küçücük bir toz zerresi olduğunu fark edince sürekli dönüp durarak "Herkes iyi, biz kötüyüz; herkes buğday gibi değerli ve gerekli, biz ise saman gibi havai ve gereksiziz" şeklinde zikredecektir.

İkinci terciibentteki yedi bent içinde öne çıkan hususları sıralayacak olursak bu bentlerde, "İlahi aşka talip olanlar daima meyhanede hazır bulunacakları bir makam edinmeli, ellerinde şarap kadehi tutarak sabah akşam durmadan sarhoşça devretmeli; ar ve namusu hiçe sayarak zamanı ve mekânı unutup kendilerinden geçmeli, aşk ve şevk ile dönüp durmalılar. Aşk ve niyaz ehli olanlar sürekli "Ey naz şahı, ömür kısa, yardım az, derdime bir çare kıl, bana aşkının ateşini ve senin yolunda yok olmayı nasip et" diyerek devran etmeli, bu yolda aklı terk ederek gerçek aşka ulaşmalıdırlar. 
İki terciibentte de nasihat unsurları ve "İşitin, dinleyin" hitapları ön planda olup vaaz ve irşat geleneğinin devamı olarak dikkat çekmektedir. Mevlevilikteki sema unsuruna da bu şiirlerde yer verilmiştir. Şair, vahdet-i vücut felsefesi çerçevesinde, kainattaki her şeyin mutlak olan vücudun birer zerresi olduğunu ve bu zerrelerin tamamının bütüne ulaşmak, ona vâsıl olmak için sürekli dönmekte olduğunu vurgulamıştır. Özellikle aşk yolunun yolcuları, meyhane olarak nitelendirilen bu aşk mektebinde ilahî şarabın etkisiyle sarhoşlukla dönmekte ve bütüne ulaşmaya can atmaktadırlar.

\section{Sonuç}

“Barça Yahşı Men Yaman/Barça Buğday Men Saman” dizesi Türk-İslam tasavvufunda en büyük düşman olan nefsin, benliğin yerilmesi için önemli bir vasıta olmuştur. "Her Geçeni Hızır Bil/Her Geceni Kadir Bil” dizesi ise bir Müslümanın nasıl yaşaması gerektiğini göstermesi ve hayata bakış açısını şekillendirmesi açısından önem arz etmiştir. Seyyid Nigârî de şiirlerinde Ahmet Yesevî’nin ve Süleyman Hakîm Ata'nın dinîtasavvufî̀ ve edebî geleneğini devam ettirmiştir. O, Hoca Ahmet Yesevî’nin çayla ilgili menakıbından hareketle tasavvufî̀ içerikli meşhur Çaynâme mesnevisini yazmış, bu eserinde Türkistan'a, Türkistan piri Hoca Ahmet Yesevî’ye ve bütün Türkistan evliyalarına göndermelerde bulunmuştur. Yeseviye ile Nakşibendiye arasındaki ortak unsurlara, Seyyid Nigârî’nin uzlaştırıcı tavrıyla Mevleviliği de eklediği; özellikle Mevlevilikteki ney ve sema kavramlarını ön plana çıkardığı görülmektedir.

Seyyid Nigârî, bu eserinde Türkistan tasavvuf erbabını aynı zamanda Azerbaycan'ın, özellikle Şirvan ve Karabağ'ın mutasavvıflarıyla da buluşturmuştur. O, Horasan'dan Orta Asya’ya geçerek Kafkaslara ve Anadolu'ya, oradan da Balkanlara doğru yayılan Türk tasavvuf tarihinin önemli temsilcilerini bu mesnevide teker teker anmıştır. Bu eserden hareketle, çay kültürünün maişette ve edebiyatta, özellikle tasavvuf edebiyatında varlığını devam ettirip yaygınlık kazanmasında Ahmet Yesevî kadar Seyyid Nigârî’nin de önemli etkisinin olduğu görülmektedir. Ahmet Yesevî’nin öğrencisi Süleyman Hakîm Ata'ya atfedilen dizeleri iki terciibendinde kullanan Seyyid Nigârî, önemli birçok dinî-tasavvufî unsuru ve hikmet geleneğinin özelliklerini bu şiirlerde ortaya koymuştur.

Bu iki dizeden hareketle, 12. yüzyıldan 19. yüzyıla kadarki Türk tasavvuf edebiyatının temel mazmun ve kavramlarının yeniden yorumlanarak günümüze kadar ulaştırıldığı görülmektedir. Bu dizeler etrafında şekillenen ve insanoğlunun yaşamına yön veren bu duygu ve düşünceler Seyyid Nigârî’nin bu iki terciibendinde pekiştirilerek tasavvuf edebiyatında ve kültür tarihimizde varlığını korumuştur. 
Bayram, P. (2021). Süleyman Hakîm Ata'dan Seyyid Nigârî’ye Ahmet Yesevî geleneğinin devamı yahut iki beytin izinde. Humanitas, 9(18), 33-52.

19. yüzyıla kadarki tasavvuf edebiyatında varlığını devam ettiren bu dizeler günümüzde bile "Her geleni Hızır bil, her geceni Kadir bil” ve "Eller yahşı men yaman/Eller buğday men saman” şeklinde halk arasında birer mesel olarak kullanılmaktadır. Tasavvufi içerikli bu dizeler hem Anadolu hem de Azerbaycan Türk toplumunun sosyal ve manevi yaşamındaki yol gösterici özelliğini bugün de muhafaza etmektedir. 


\section{Kaynakça}

Ali b. Hüseyin b. Ali el-Vaiz el-Kâşifî (1853) Reşahât-l Aynü'l-Hayat. https://katalog.marmara.edu.tr/eyayin/pdf/F01735.pdf

Algar, H. (1996). Hâcegân. Türkiye diyanet vakfi İslâm anskilopedisi içinde (14, s. 431). İstanbul: Türkiye Diyanet Vakfı Yayınları.

Arat, R. R. (1964). Hakîm Ata. Millî eğitim bakanlı̆̆ı İslam ansiklopedisi içinde (5, s. 101103). İstanbul. Millî Eğitim Bakanlığı Yayınları.

Bayram, P. (2008a). Karabağlı Seyyid Mir Hemze Nigârî’nin heyatı, yaradıcılı̆̆l ve Türkçe divanının poetik strukturu. Bakı: Azerbaycan Milli Bilimler Akademisi Nizami Adına Edebiyat Enstitüsü (Yayımlanmamış Doktora Tezi).

Bayram, P. (2008b). Seyyid Nigârî’nin Çayname mesnevisi. Bakü Devlet Üniversitesi Dil ve Edebiyat Dergisi. Uluslararası İlmi-Nazari Dergi, 2(62), 133-137.

Bice, H. (2015). Hoca Ahmet Yesevî, günümüzün aşk yolcusu: Divan-ı Hikmet. İstanbul: H Yayınlar1.

Bilgin, A. (2017). Dîvân-ı Nigârî. https://ekitap.ktb.gov.tr/Eklenti/55757,nigaridivanipdf.pdf?0

Demirci, M. (1996). Türkistan notları-Yesevî diyarında 6 ay. İstanbul: Kubbealtı Neşriyatı.

Eraydın, S. (1997). Tasavvuf ve tarikatlar. İstanbul: Marmara Üniversitesi İlahiyat Fakültesi Yayınlar1.

Güzel, A. (2008). Süleyman Hakîm Ata'nın Bakırgan kitabı üzerine bir inceleme. Ankara: Öncü Basımevi.

Kara, M. (1990). Tasavvuf ve tarikatlar tarihi. İstanbul: Dergâh Yayınları.

Kara, M. (1997). Hakîm Ata. Türkiye diyanet vakfi İslam ansiklopedisi içinde (15, s. 183184). İstanbul: Türkiye Diyanet Vakfı Yayınları.

Kısakürek, N. F. (2015). Reşahât tercümesi. İstanbul: Büyük Doğu Yayınları.

Köprülü, M. F. (1976). Türk edebiyatında ilk mutasavvıflar (3. bask1). Ankara: Türk Tarih Kurumu Basımevi.

Kur'an-ı Kerim (2018). İstanbul: Diyanet İşleri Başkanlığı Yayınları.

Kutlu, H. (2013). Hülâsatü'l-hakâyık ve mektûbât-l Hâce Muhammed Lutfî. İstanbul: Efe Hazretleri Vakfı Yayınları. 
Bayram, P. (2021). Süleyman Hakîm Ata'dan Seyyid Nigârî’ye Ahmet Yesevî geleneğinin devamı yahut iki beytin izinde. Humanitas, $9(18), 33-52$.

Okuyucu, C. (1995). Hazini: Cevahirü'l-ebrâr min emvâc-l bihâr. Kayseri: Erciyes Üniversitesi Gevher Nesibe Tıp Tarihi Enstitüsü Yayını.

Sever, M. (2018). Bakırgan kitabı. Ankara: Ahmet Yesevi Üniversitesi Mütevelli Heyeti Başkanlığı Yayınları.

Tosun, N. (2008). "Reşehât". Türkiye diyanet vakfi İslâm anskilopedisi içinde (35. s. 8-9). İstanbul: Türkiye Diyanet Vakfı Yayınları. 